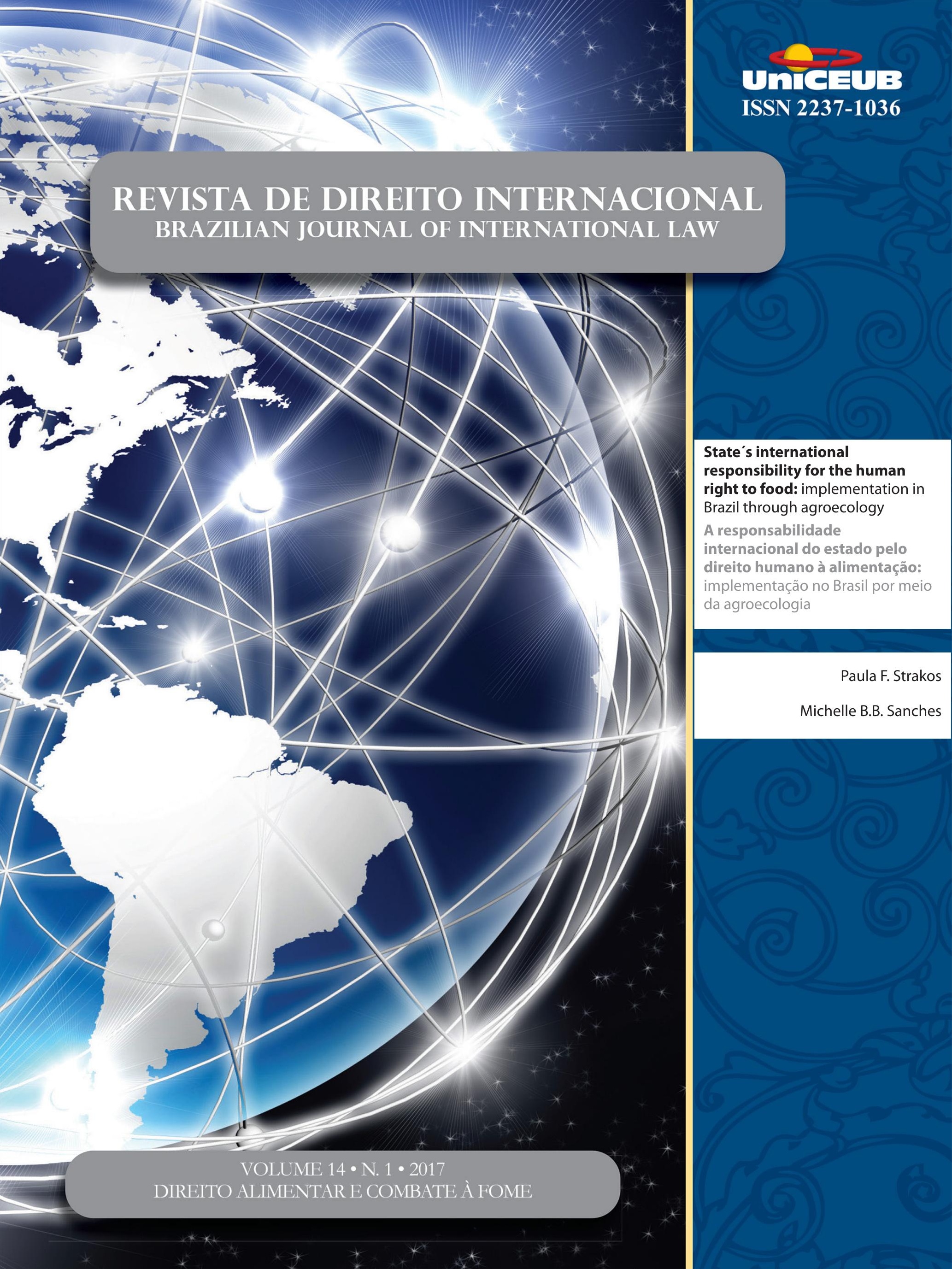




\section{Sumário}

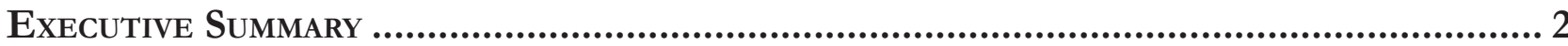

Daniel Balaban

Crônicas Sobre o Direito Alimentar e o Combate À Fome .............................................. 5

South-South Food and Nutrition Security promotion: the Brazilian experience

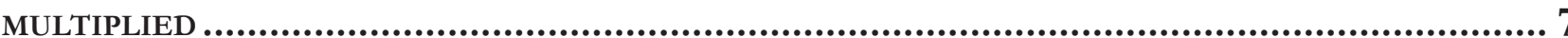

João Almino

Access to Food as a Human Right: Brazil, WFP and South-South Cooperation .......10 Carlos R. S. Milani

Dossiê temático: Direito Alimentar e Combate à Fome 13

WFP'S ROLE IN BUILDING SUSTAINABLE BRIDGES BETWEEN THE RIGHT TO ADEQUATE FOOD AND THE FREEDOM FROM HUNGER 15

Christiani Amaral Buani e Bruno Valim Magalhães

Direito humano À ALIMENTAÇÃo, (IN) SEgURANÇA ALIMENTAR E DESENVOLVIMENTO: OS DESAFios à REALIZAÇão PROGRESSIVA Na AMÉrica LATINa

Sinara Camera e Rubia Wegner

STATE'S INTERNATIONAL RESPONSIBILITY FOR THE HUMAN RIGHT TO FOOD: IMPLEMENTATION IN BRAZIL THROUGH AGROECOLOGY

Paula F. Strakos e Michelle B.B. Sanches

NegotiatiNg agRiCULtURE IN THE WORLD TRADE ORgANIZATION: FOOD SECURITY AS A NON-TRADE CONCERN.

Ana Luísa Soares Peres e Letícia de Souza Daibert

QUANDO HABITAR CORRESPONDE AO DIREITO HUMANO À ALIMENTAÇÃO

Fernanda Viegas Reichardt e Maria Elisa de Paula Eduardo Garavello 
The ROLE OF SUSTAINABLE LEARNING POLICIES ON THE FIGHT AGAINST

HUNGER IN ADULT EDUCATION.

Hiran Catuninho Azevedo

O DIREITO HUMANO E FUNDAMENTAL À ALIMENTAÇÃo ADEQUADA E À CONDIÇÃo

FEMININA NO PROGRAMA BOLSA FAMÍlIA: EMPODERAMENTO ÀS AVESSAS?

Rosalice Fidalgo Pinheiro e Laura Garbini Both

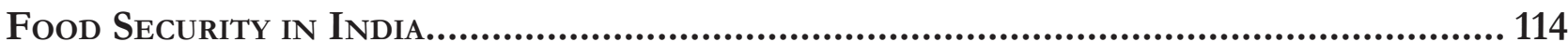

Ranjana Ferrão

SEguranÇA ALIMENTAR E A GOVERnANÇA ECONÔMICA GLOBAL

Danielle Mendes Thame Denny, Douglas de Castro, Alexandre Ricardo Machado, José Valverde Machado Filho e Gabrielle Fontes Witt

Outros Artigos.

The legal implications of the Draft Universal Declaration of the Rights of MANKIND

Catherine Le Bris

Litigating Indigenous Dispossession in THE Global Economy:

Law's Promises and Pitfalls................................................................................ 165

Charis Kamphuis

UNE DÉFINITION DU PRÉ-INVESTISSEMENT CONFORME À L'APPROCHE FRANÇAIS MAIS CONTRAIRE À L'APPROCHE AMÉRICAINE AU SEIN DES TRAITÉS BILATÉRAUX D'INVESTISSEMENTS IRANIENS

Peyman Dadras

CONFLITOS ENTRE REGULAÇÕES INTERNAS RELATIVAS À INTERNET E O DIREITO DO COMÉRCIO INTERNACIONAL: O PAPEL DA OMC PERANTE O SISTEMA DE COMPUTAÇÃO DA NUVEM ............238

Alice Rocha da Silva e Filipe Rocha Martins Soares

Prélèvement: origem, EVoluÇão e ocaso do Privilégio NAS SuCESSÕes INTERNACIONAIS NA FRANÇA

Fernando Pedro Meinero 
OS CONTRATOS INTERNACIONAIS DE FINANCIAMENTO E O CENTRO FINANCEIRO DE

Nova IorQue: CONSIDERAÇões SOBRE A AUTONOMIA DA VONTADE

Fernanda Torres Volpon

Mercosul e o Meio ambiente: ANÁlise da tUTELA REgional AMBIENTAL 284 Clarissa Ferreira Macedo D'Isep

Ainda (E uma Vez MAis) o SILÊNCIO QUe ENTOA O TRIUNFo De Lewis Carrol: A Regra N ${ }^{\circ} 42$ do Supremo Tribunal Federal

Thiago Aguiar Pádua e Bruno Amaral Machado

\section{A Natureza Jurídica do Sistema de Solução de Controvérsias da OMC} E DE SuAs Decisões: Solucionando um Imbróglio 316

Camila Capucio

Brics: Desafios do DESENVOLVIMENTO ECONÔMICO E SOCIOAMBIENTAI Magno Federici Gomes e Luís Eduardo Gomes Silva

REVER OU ROMPER COM VESTFÁLIA? POR UMA RELEITURA DA EFETIVA CONTRIBUIÇÃO DOS ACORDOS DE PAZ DE 1648 À CONSTRUÇÀO DO MODELO VESTFALIANO DE ESTADOS.

Luiz Magno Pinto Bastos Junior

Justiça de Transição EM SUA GÊNESE: A Alemanha Pós-NAZismo 378 Bruno Galindo

Quando JUlgar SE TORNa UM ESPETÁCulo: A INTERAÇão ENTRE o Supremo Tribunal Federal e a opinião pública, A PARTIR de REFlexões da LITERATURA ESTRANGEIRA

Patrícia Perrone Campos Mello

TolerânCia E refugio: um ENSAIO A PARTIR do ACORdo EU-TurQuia 425 Flávia Cristina Piovesan e Ana Carolina Lopes Olsen 


\title{
State's international responsibility for the human right to food: implementation in Brazil through agroecology*
}

\author{
A responsabilidade internacional do \\ estado pelo direito humano à alimentação: \\ implementação no Brasil por meio da \\ agroecologia
}

Paula F. Strakos**

Michelle B.B. Sanches***

\begin{abstract}
This paper analyzes the implementation of the international obligation to the progressive realization of the human right to food (HRF) by the Brazilian State with a special focus on public policy to promote agroecological practices. The aim therein is to evaluate the potential benefits of the use of agroecology as means to implement the HRF as well as identify potential areas for further development. First, a historical and legal examination of the HRF will shed light on its current legal framework, on its detailed normative content and on the State's obligation arising therefrom, with a focus on agroecological practices as means to its implementation. In a second section, we will analyze the implementation of the HRF in the Brazilian legal system, including its applicable institutional framework and the most relevant public policies. We conclude that the application of agroecological public policy in Brazil constitutes a relevant opportunity to positively address several obstacles found in previous public policy such as the contradictions resulting from the lack of integration in a complex net of institutions. The analyses of the Brazilian agroecological framework shows that the normative content of the HRF can be addressed and implemented through this strategy. The Brazilian experience could and should be used as a building block for further development towards a more effective implementation of the HRF by integrating social, economic and environmental concerns through agroecology.
\end{abstract}

Keywords: Human right to food. Food security. Agroecology. State obligation. Sustainability. Brazil. Public policy.

\section{Resumo}

Este artigo analisa a implementação da obrigação internacional da realização progressiva do Direito Humano à Alimentação (DHA) pelo Estado Brasileiro com foco especial nas políticas públicas que promovem práticas agroecológicas. O escopo deste estudo é avaliar os potenciais benefícios do 
uso da agroecologia como uma forma de implementação ao DHA assim como identificar potenciais áreas a serem desenvolvidas. Primeiramente, um exame histórico e normativo do DHA trará luz ao seu contorno jurídico, seu conteúdo normativo e à obrigação Estatal decorrente do DHA, com foco em práticas de agroecologia como forma de sua implementação. $\mathrm{Na}$ segunda seção, analisaremos a implementação do DHA no sistema legal brasileiro, incluindo sua estrutura institucional e as políticas públicas mais relevantes. Concluímos que a aplicação da política pública voltada à agroecologia no Brasil constituí uma relevante oportunidade para endereçar positivamente diversos obstáculos encontrados em políticas públicas anteriores, tal como as contradições resultantes da falta de integração de uma complexa rede institucional. A análise do contorno jurídico para implementação de práticas agroecológicas no Brasil evidencia que relevantes aspectos do conteúdo normativo do DHA podem ser endereçados e aplicados por meio desta estratégia. A experiência brasileira pode e deve ser utilizada como alicerce para progressiva e efetiva implementação do DHA, integrando interesses sociais, econômicos e ambientais através da agroecologia.

Palavras chave: Direito humano à alimentação. Segurança alimentar. Agroecologia. Obrigação estatal. Sustentabilidade. Brasil. Política pública.

\section{INTRODUCTION}

Even though the world produces enough food to provide every human being with an adequate diet, ${ }^{1}$ there are still, in the second decade of the 21 st century, estimated 795 million undernourished people, ${ }^{2}$ corresponding to approximately one over nine people on the earth. The international community has long ago acknowledged the primarily role of food security for life in dignity and recognized the human right to food

1 FOOD AND AGRICULTURE ORGANIZATION OF THE UNITED NATIONS. Anti-Hunger Programme. A twin-track approach to hunger reduction: priorities for national and international actions. Rome: FAO, 2002, p. iii - first page of the executive summary. Available at: <ftp://ftp.fao.org/docrep/fao/006/j0563e/ j0563e00.pdf>. Access on: 06 jan. 2017.

2 FOOD AND AGRICULTURE ORGANIZATION OF THE UNITED NATIONS; IFAD; WFP. The State of Food Insecurity in the World 2015. Meeting the 2015 international hunger targets: taking stock of uneven progress. Rome: FAO, 2015. Available at: <http:// www.fao.org/3/a-i4646e.pdf>. Access on: 06 jan. 2017.
(HRF) as binding international law for signatory states of the International Covenant for Economic, Social and Cultural Rights (ICESCR) and other international agreements, with corresponding state obligation. Nevertheless, the definition of the exact normative content and corresponding state obligation for the HRF is still an ongoing process and has only in the last decades attained sharper outlines. Even more recently the international community renewed its commitment to eradicate hunger until 2030 as key commitment under the Sustainable Development Goals (SDGs).

Hunger and poverty are intrinsically linked so that one cannot be solved without the other. Both issues concentrate mainly in rural areas of developing countries, amounting to $75 \%$ of the people living in hunger being in the rural areas of developing countries. ${ }^{3}$ Thus, enhancing the productivity of family farmers is a key element not only in the fight against hunger and poverty, but also to set the conditions for inclusive economic growth. Moreover, empowering family farmers to produce agroecological food is an alternative that might build resilience urgently needed by the most vulnerable climate change victims and at the same time, achieve social and environmental sustainability, as deeper analyzed below.

On the other side of the social spectrum, the urban and more affluent part of population, mostly in economic developed parts of the globe, is increasingly changing its food demands towards secure food production for human health and the environment as well as, to a smaller extent, socially just and regional food production. Herrings point out that "food politics does not disappear with success in the historical struggle with scarcity, but does acquire new dimensions." ${ }^{4}$ Food politics in the financially developed world has turned into a path for self-expression and its effects can be most prominently seen in the outgrowth of the transnational organic social movement and the major shifts it has generated in the food market, ${ }^{5}$ representing an important

3 FOOD AND AGRICULTURE ORGANIZATION OF THE UNITED NATIONS; IFAD; WFP. Reducing Poverty and Hunger: The critical Role of Financing Food, Agriculture and Rural Development. Rome: FAO, 2002. p. 12. Available at: <ftp://ftp.fao.org/ docrep/fao/003/Y6265E/Y6265E.pdf>. Access on: 06 jan. 2017.

4 HERRING, Ronald J. How is food political? market, state and knowledge. In: __ (Ed.). The Oxford handbook of food, politics and society. New York: Oxford University, 2015. p. 8

5 For more in this regard see: WILLER, Helga; YUSSEFI-MENZLER, Minou; SORENSEN, Neil (Ed.). The world of organic agricul- 
call for social and environmentally safe food production.

The apparent dichotomy between the harsh realities faced by rural population and the affluent urban population can be brought together to benefit the totality of society. Agroecological food production is a promising path on that direction and might play a decisive role for States to implement their international human rights obligations for food. Especially in a country like Brazil, with a major social inequality gap and where the distant realities of rich and poor meet on a common space in everyday life, agroecology might represent a decisive strategy to socially and economically include small holder farmers, while at the same time addressing the urgent need for environmentally sustainable use of land and attend the demand for healthier food production.

Regarding State's behavior towards the realization of the HRF, the former Special Rapporteur ${ }^{6}$ of the HRF identified a deep contradiction in the global efforts to realize human rights in general and the HRF in particular. Such contradiction is referred to as a "schizophrenia in the United Nations System and in State's public policy." ${ }^{\prime \prime}$ On the one side, the international community as well as individual States recognize and take measures to implement the HRF. The latest step in this direction by the international community was the compromise made through the SDG to end hunger by 2030 . On the other hand, the United Nations agencies and States individually approve and implement measures that have a direct negative effect on food production and markets, especially harming small scale farmers and the most vulnerable rural population. Examples are deregulation and agricultural trade liberalization agreements, such as the currently discussed Transatlantic Trade and Investment Partnership (TTIP), or the approval of corporate centralization of big global agricultural input companies, such as the acquisition of Monsanto, the highly controversial and largest seed company in the world, by Bayer AG, a major drug and crop chemical maker.

In order to demand from States, both in court and in the political arena, that public policy respect, protect

ture: statistics and emerging trends. Bonn: IFOAM, 2008.

6 The Special Rapporteur is an independent expert appointed by the Human Rights Council to analyze and report about the implementation of the HRF by member States. See Resolution 2000/10, April, 2000, Human Rights Council.

7 ZIEGLER, Jean et al. The fight for the right to food: lessons learned. Geneva: The Graduate Institute Publications, 2011. p. xii. and fulfill the HRF, it is cardinal to promote a legal debate to crystallize the State's obligation arising from the normative framework of the HRF. This article aims to contribute to the discussion of the State's responsibility for the HRF with a multilevel approach from international law, national law and public policy as means of implementation of international human rights obligations. The first part will focus on the international arena, contextualizing the HRF historically, untangling its normative content and analyzing the role of agroecology as means of its implementation through a conceptual method. In the second part we will analyze the use of agroecology by the Brazilian State, as means of progressive implementation of the HRF in order to identify its compliance and/or non-compliance with its international legal obligation. For such purposes, we will make a brief descriptive exposure of the Brazilian legal and institutional framework for the implementation of HRF and related public policies, focused on agroecological practices, followed by an analytical evaluation of the compliance by the Brazilian State of its human rights obligation. We do not intend to make an exhaustive analysis of the Brazilian institutional framework nor to compare public policy towards the implementation of HRF, but rather analyze the role of agroecology as means of implementation of HRF in Brazil.

\section{Historical deVELOPMENT OF THE HUMAN RIGHT TO FOOD}

The recognition of the HRF can be traced back to the emergence of the human rights regime itself through the Universal Declaration of Human Rights (UDHR) in 1948. The UDHR included the HRF as a component of the right to an adequate standard of living in Article 25, para. 1. Equally, the HRF has been expressly included in the complementary treaty to the UDHR, the International Covenant on Economic, Social and Cultural Rights (ICESC) in Article 11. Nevertheless, the HRF framework did not received significant legal attention in the international arena until the late 1990.

Before this point, the international debate on the subject revolved around the concept and implementation strategies of food security with a focus on food availability and public policy to improve food production. The challenge to feed a fast growing population 
was addressed through technological advancement in high-yielding crop varieties and public investment in infrastructure, including price incentives and irrigation infrastructure to support the use of those crops. This process resulted in the so-called Green Revolution which started in the mid-1960s and reached its high point of productivity between 1980 and 1990 when successive generations of genetically modified crops were developed and inserted into the market ${ }^{8}$. The Green Revolution was a success in terms of an increase in productivity capability pro hectare and was a remarkable achievement in regards to lowering food prices globally and solving the material demand for food. Since then, there is a general consensus that the world produces enough food to feed the global population.? Although the Green Revolution contributed to the solution, it could not solve the problem of hunger and malnutrition in the world. The extremely poor and poor people in the world, approximately 795 million in $2015,{ }^{10}$ continue to be undernourished.

Apart from not solving the problem of hunger, the Green Revolution also had significant side effects from social and environmental perspectives. On the environmental level, the intensive application of industrialized monoculture plus intense uses of water, fertilizers and pesticides, have caused an increasing pressure of ecosystem services and led to high rates of land degradation, land nutrient run-off, water system pollution from farm waste and chemical inputs, water depletion through excessive use, less resilience through reduced genetic diversity and, ultimately, contributed to climate change. ${ }^{11}$ On the social level, the agriculture tech-

8 EVENSON, R. E.; GOLLIN, D. Assessing the impact of the green revolution: 1960 to 2000. Science, v. 300, n. 5620, p. 758-762, May. 2003. p. 759.

9 FOOD AND AGRICULTURE ORGANIZATION OF THE UNITED NATIONS. The State of Food Insecurity in the World. 2002. Foreword. Available at: <http://www.fao.org/docrep/005/y7352e/ y7352e02.htm\#TopOfPage>. Access on: 15 out. 2016; FARMER, B. H. Perspectives on the 'Green Revolution' in South Asia. Modern Asian Studies, v. 20, n. 01, p. 175-199, 1986.

10 FOOD AND AGRICULTURE ORGANIZATION OF THE UNITED NATIONS. The State of Food Insecurity in the World 2105. Rome: FAO, 2015. p. 26. Available at: <http://www.fao.org/3/ai4646e/index.html> Access on: 15 out. 2016.

11 Some 40 percent of agricultural land has been strongly or very strongly degraded in the past 50 years by erosion, salinization, compaction, nutrient depletion, biological degradation, or pollution. MILLENNIUM ECOSYSTEM ASSESSMENT. Ecosystems and buman well-being: a framework for assessment. Washington, DC: World Resources Institute, 2005. p. 64. Available at: <http://www.millenniumassessment.org/documents/document.300.aspx.pdf $>$ Access niques implemented during the Green Revolution did not necessarily benefit the small holder farmers. On the contrary, in some occasions, it contributed to the increasing marginalization and elimination of small-hold local farmers or traditional communities. This is because the new agriculture technology is highly dependent on external inputs such as agrochemicals and the transgenic seeds themselves, which small-hold or traditional farmers might not have been able to either afford or compete with. ${ }^{12}$ Deep irony lies in the fact that the rural population of developing countries accounts for the majority of the world population suffering from food insecurity. ${ }^{13}$

This led the international community to realize that the problem of hunger and malnutrition had a much stronger link to food access, poverty and social inequality, rather than the availability of food itself. The concept of food security developed accordingly and shifted its focus from food availability to include the elements of (1) access to food, and in the following decades, to include the elements of (2) utilization, to address nutritional considerations and qualitative aspects, (3) risk, to address vulnerability, and lastly, and (4) sustainability, to allow food security for present and future generations. ${ }^{14}$

The concept of food security was approved by the international community at the World Food Summit 1996, including all of the elements mentioned above as follows: "Food security exists when all people, at all times, have physical and economic access to sufficient, safe and nutritious food to meet their dietary needs and food preferences for an active and healthy life." ${ }^{15}$ The concept of food security is continuously evolving

on: 20 out. 2016.

12 See: ELVER, Hilal. Interim report of the Special Rapporteur on the right to food, Promotion and protection of human rights: human rights questions, including alternative approaches for improving the effective enjoyment of human rights and fundamental freedoms, UN Doc. A/70/287, 2015. p. 20; WEINGÄRTNER, Lioba; TRENTMANN, Claudia (Ed.). Handbuch Welternährung. Frankfurt: Campus Verlag, 2010. p. 55.

13 FOOD AND AGRICULTURE ORGANIZATION OF THE UNITED NATIONS. The State of Food Insecurity in the World 2105. Rome: FAO, 2015. p. 26. Available at: <http://www.fao.org/3/ai4646e/index.html > Access on: 15 out. 2016.

14 BROWN, Lynn; GENTILINI, Ugo. On the edge: the role of food-based safety nets in helping vulnerable households manage food insecurity. In: GUHA-KHASNOBIS, Basudeb; ARCHARYA, Shabd S.; DAVIS, Benjamin (Ed.). Food insecurity, vulnerability and buman rights failure, (no location). Basingstoke: Palgrave Mcmillan, 2007. p. 82-105. p. 83.

15 Art. 1, World Food Summit Plan of Action. 
as an operational concept in public policy to address the complexities of the subject. ${ }^{16}$ Most recent concerns have addressed the need to create resilience for climate change caused weather variations. Climate change poses a unique threat to food security, including the aspects of availability, accessibility, adequacy and sustainability.

The historical development of the concept of food security shows how the way forward to end hunger and malnutrition requires political and legal engagement rather than complicated technical solutions. The concept of food security carries a significant legal weight but is not binding upon States. The HRF adds the vital element of accountability to food security.

The World Food Summit in 1996 was also a milestone in the acknowledgment of the need to implement a rights-based approach to food security. On that occasion, states reaffirmed the human right to be free from hunger, agreed on the goal to reduce the number of the hungry people in the world in half by 2015, and gave the High Commissioner for Human Rights a specific mandate to further develop the normative content of the HRF and the corresponding state obligation. ${ }^{17}$

After the World Food Summit, the Committee on Economic, Social and Cultural Rights (CESCR) released in 1999 General Comment no. 12 on the right to adequate food (General Comment no. 12) in its capacity as a monitoring institution of the ICESCR implementation. ${ }^{18}$ Although general comments have a soft law character, they are an authoritative interpretation so that any disagreement by the signatory-States must be legally justified.

The interpretation made in General Comment no. 12 was later endorsed by member-States through the Voluntary Guidelines on the Right to Food (VGRF). The VGRF were prepared by States as a response to the poor development of the compromises assumed in the World Food Summit in 1996 and represent a major effort by the international community to set a clear fra-

16 FOOD AND AGRICULTURE ORGANIZATION OF THE UNITED NATIONS. Trade Reforms and Food Security. Rome: FAO, 2003. p. 25-33. Available at: <ftp://ftp.fao.org/docrep/fao/005/ y4671e/y4671e00.pdf > . Access on: 21 out. 2016.

17 World Food Summit Plan of Action, Objective 7.4.

18 RAE, Isabella; THOMAS, Julian; VIDAR, Margret. The right to food as a fundamental human right: FAO's Experience. In: GUHA-KHASNOBIS, Basudeb; ACHARYA, Shabd S.; DAVIS, Benjamin (Ed.). Food insecurity, vulnerability and buman rights failure. New York: United Nations University, 2007. p. 266 f. mework for state obligations to the HRF. ${ }^{19}$ The VGRF was unanimously approved by States in the 127th Session of the FAO Council in November 2004 and carries a soft law nature. Although soft law instruments are not immediately binding upon States, they have significant legal and political weight and build the base for the crystallization of binding law, ${ }^{20}$ including customary law and general principles of international law. ${ }^{21}$ Additionally, soft law inverts the burden of proof so that the noncompliance of requirements established in VGRF, must be duly justified by States, who cannot allege ignorance or refusal to implement the established steps.

\section{NORMATIVE CONTENT OF THE HUMAN RIGHT TO FOOD}

The CESCR established that the right to adequate food is only realized when "every man, woman and child, alone or in community with others, has the physical and economic access at all times to adequate food or means for its procurement." 22 The normative content of the HRF entails the elements of Availability, Accessibility, Adequacy and Sustainability.

Availability refers to the presence of food in a quantity and quality sufficient for human nutritional needs either made available from natural environment or from the food market. The availability criterion in the natural environment is especially relevant for rural and indigenous populations. It is not met when unsustainable uses of land result in land degradation or forest destruction that prevent the local population from extracting its livelihood from nature or when unsustainable uses or water pollution result in shortages that do not satisfy the basic needs of subsistence agriculture or prevents subsistence fishery activities.

Accessibility refers to physical as well as economical access to food. For economic access to be complied with, the individual's or group's capacity to pay for adequate food must not compromise her/his/their capability to provide for other basic needs also protected

19 ZIEGLER, Jean et al. The fight for the right to food: lessons learned. Geneva: The Graduate Institute Publications, 2011. p. 6-7.

20 HOBE, Stephan. Einführung in den Völkerrecht, 9. Auflage, Tübingen und Basel 2008. p. 206.

21 Laskowski, Silke.

22 General Comment no. 12, para. 6. 
by human rights. Physical accessibility refers to barriers that might prevent an individual or group from having actual access to adequate food, such as older or disabled people, or an indigenous group of people that is hindered from accessing parts of its traditional territory that are essential for their nourishment.

The normative element of adequacy refers to the nurturing qualities of the food and requires it to satisfy dietary needs, to be safe for human consumption, "free from adverse substances" and acceptable within a given culture. $^{23}$

The element of sustainability incorporates the notion of long term availability and accessibility for present and future generations. Even with the exacerbated scientific and technological development in the last century, human knowledge about how to use natural resources and environmental services in a sustainable manner is still controversial. This is reflected in Art. 11(2)(a), ICESCR, upon which the signatory-States expressly include their commitment to improve methods of food production making full use of technical and scientific knowledge to effectively use natural resources.

The ways to achieve sustainability in agriculture is a highly political and controversial. Nevertheless, sustainability in the context of the HRF must be holistically understood and encompass environmental, social, health and resilience aspects. Considering that the majority of people suffering from hunger and malnourishment are in rural areas of the developing world, sustainable agriculture is a path to empower the farmer not only to immediately feed herself/himself out of hunger and undernourishment, but also might be a path out of poverty with support of effective public policy. ${ }^{24}$

\section{State's obligation to the human Right to FOOD}

With a clear vision of the normative content of the HRF, it is possible to extract the State's obligation towards the fulfilment of the right. As any other ESCRight, the HRF is subject to a progressive realization by Sta-

23 General Comment no. 12, para. 8.

24 See FOOD AND AGRICULTURE ORGANIZATION OF THE UNITED NATIONS. Small-scale Agriculture for Inclusive Development in the Near East and North Africa. 2015. Available at: <http:/ / www.fao.org/3/a-au207e.pdf>. Access on: 28 out. 2016. te according to Art. 2 ICESCR. This means that States are not obliged to immediately fully realize all aspects of the HRF but that they must undertake steps, to the maximum of their available resources, to progressively realize the HRF. States are also forbidden to approve any regressive policies that would negatively affect progress in access to adequate food. Nevertheless, the HRF contains core obligation that have immediate effect and cannot be implemented step by step. In essence, the core obligation of the HRF is to mitigate and alleviate hunger even in times of natural or other disasters, economic instability, war or otherwise as provided for in Art. 11, para. 2, ICESCR. Another State obligation with immediate effect is the prohibition to discriminate in access to food on the basis of gender, color, religion, origin, political or other opinion, property, birth or other status, as of Art. 2, para. 2 and Art. 3 ICESCR.

General Comment no. 12 applied the established tripartite division of State's obligation for human rights, namely the respect, protect and fulfill framework. Under the obligation to respect, States must restrain from taking any measures that result in preventing the existing access to adequate food. It constitutes a negative obligation that limits the exercise of State power for any measures that could arbitrarily restrict or impel the existing realization of the HRF. This is the case if States evict people from land that provides their primary access to food or when social security nets are withdrawn from people who do not have any other way to maintain access to adequate food. Another relevant example for the breach of the responsibility to protect are State measures that authorize or incentivize the use of toxic substances in food production that are known to cause harm to human health, once it is part of the normative element of adequacy, for the food to be free from adverse substances. ${ }^{25}$

Under the obligation to protect, the State must take measures to ensure that third parties, either companies or individuals, do not deprive individuals of their access to adequate food. This obligation is positive and requires States to actively take measures through regulation and supervision of non-State actors that harm the exercise of the HRF. This includes regulating situations that lead to discrimination in food access or situations to protect the right to information of consumers. Examples of breaches are the pollution of rivers or soil by

25 ZIEGLER, Jean et al. The fight for the right to food: Lessons Learned. Geneva: The Graduate Institute Publications, 2011. p. 19. 
companies or individuals that prevent rural people from extracting their food from rivers or land.

Finally, the State must, under its obligation to fulfill, pro-actively engage in activities to strengthen individual access to and utilization of resources and means to ensure their livelihood, including food security. The primary obligation is to facilitate the realization of the right by the individuals or groups, but this shifts into an obligation to provide the right directly whenever an individual or group is unable, for reasons beyond their control, to enjoy the right to adequate food by the means at their disposal. It is also applicable in circumstances of natural disasters, climate change and financial instability. Additionally, the positive obligation to fulfil the HRF also includes measures to identify and address the special circumstances of vulnerable groups such as the rural population, landless people, children, women, indigenous population, among others. Providing the means to have access to food to people that otherwise would not have been able to do so is not a matter of charity but rather a right to human dignity. ${ }^{26}$ Letting people starve is a grave violation of the HRF as well as to the right to life and human dignity.

Additionally, the VGRF has contributed to the clarification of States' obligation to the HRF by expressly recognizing the need for a holistic approach to development in order to realize the HRF, which includes the protection of other inseparably connected rights such as the rights to safe drinking water and the highest attainable standard of health. Recognizing that all human rights are universal, indivisible, interdependent and interrelated is essential to achieve food security. ${ }^{27}$ Another important element in the realization of the HRF, according to the VGHR, is capacity development of all stakeholders that can influence the realization of the HRF, at both an individual and institutional level.

\section{Sustainable DeVELopment GoALS}

The international community has newly reaffirmed its commitment to end hunger, achieve food security

26 FOOD AND AGRICULTURE ORGANIZATION OF THE UNITED NATIONS. Implementing the Right to Adequate Food: The Outcome of Six Case Studies, IGWG RTFG Information Paper No. 4. Rome: FAO, 2004. p. 13.

27 Reinforcing the Vienna World Conference on Human Rights, Vienna Declaration und Programme of Action, 1993, Art. I.5. and improve nutrition and promote sustainable agriculture by 2030 , under the SDG no. 2. The SDGs carry significant political and legal weight as a soft law instrument and might constitute international customary law according to progressive interpretations ${ }^{28}$. The compromise contained in the SDG no. 2 is incontrovertibly linked with the legally binding State's obligation for the HRF and constitute, all together, a reinforced recognition of a State's legal duty. They contribute to a clearer definition of a State's obligation as it sets a time limit for its realization and sets a foundation for effective demands.

The SDG reinforced the recognition of the intrinsic link of hunger and poverty. Social protection and assistance are essential to achieve those goals and public investment and policy should focus on landless farmers, under the basic premise that people who are out of extreme poverty are also free from hunger. ${ }^{29} \mathrm{~A}$ wide body of evidence and literature review exists to support the fact that social safety nets, when carefully planned, can be an effective way to remove people from poverty. ${ }^{30}$

\section{THE ROLE OF AGROECOLOGY IN THE IMPLEMENTATION OF THE HRF}

The historical development of the human rights-based approach to food security reasserts the premise that more food production does not necessarily, if at all, result in less people suffering from hunger and malnutrition. ${ }^{31}$ States' human rights obligations to realize

28 See ALSTON, Phillip. Ships passing in the night: the current state of the human rights and development debate seen through the lens of the millennium development goals. Human Rights Quarterly, v. 27, p. 755-829, Aug. 2005. p. 771-775.

29 FOOD AND AGRICULTURE ORGANIZATION OF THE UNITED NATIONS. Acbieving Zero Hunger: the critical role of investments in social protection and agriculture. Rome: FAO, 2015. p. 9. Available at: < http://www.fao.org/3/a-i4951e.pdf> Access on: 28 out. 2016.

30 See BROWN, Lynn; GENTILINI, Ugo. On the edge: the role of food-based safety nets in helping vulnerable households manage food insecurity. In: GUHA-KHASNOBIS, Basudeb; ARCHARYA, Shabd S.; DAVIS, Benjamin (Ed.). Food insecurity, vulnerability and buman rights failure, (no location). Basingstoke: Palgrave Mcmillan, 2007. p. $82-105$. p. p. 82

31 ELVER, Hilal. Interim report of the Special Rapporteur on the right to food, Promotion and protection of human rights: human rights questions, including alternative approaches for improving the effective enjoyment of human rights and fundamental freedoms, UN Doc. A/70/287, 2015. p. 23; NELSON, Rebecca; COE, 
the HRF go far beyond simple availability concerns and must holistically include social and economic solutions to provide accessibility and adequacy, as well as environmental solutions to provide sustainability and adequacy. Nevertheless, the world is still facing the apparent paradox that a widely implemented strategy to solve food security challenges, namely large-scale industrial agriculture with technologies developed during the Green Revolution, is at the same time a possible solution and the cause of food insecurity by contributing to climate change, land degradation, water resources depletion and pollution and marginalization of small-farm agriculture. $^{32}$

A growing consensus can be identified in the scientific community, ${ }^{33}$ academia, ${ }^{34}$ international community ${ }^{35}$ civil society $^{36}$ and public policy, ${ }^{37}$ towards the use of agroecological practices by small holder farmers as a strategy that embraces multiple layers of State obligation for the HRF. Agroecology can be defined as the

Richard. Agroecological Intensification of Smallholder Farming. In: HERRING, Ronald J. (Ed.). The Oxford Handbook of Food, Politics and Society. New York: Oxford University Press, 2015. p. 107.

32 Some 40 percent of agricultural land has been strongly or very strongly degraded in the past 50 years by erosion, salinization, compaction, nutrient depletion, biological degradation, or pollution. MILLENNIUM ECOSYSTEM ASSESSMENT. Ecosystems and Human Well-being: A Framework for Assessment. Washington, DC: World Resources Institute, 2005. p. 64. Available at: <http:// www.millenniumassessment.org/documents/document.300.aspx. pdf> Access on: 20 out. 2016; ELVER, Hilal. Interim report of the Special Rapporteur on the right to food, Promotion and protection of human rights: human rights questions, including alternative approaches for improving the effective enjoyment of human rights and fundamental freedoms, UN Doc. A/70/287, 2015. p. 23.

33 WEZEL, A.; SOLDAT V. A quantitative and qualitative historical analyses of the scientific discipline agroecology. International Journal Agricultural Sustainability, v. 7, n. 1, p. 3-18, 2009.

34 SCHUTTER, Olivier de. Agroecology, a Tool for the Realization of the Right to Food. In: LICHTFOUSE, Eric (Ed.). Agroecology and Strategies for Climate Change. New York: Springer, 2012. p. 1-16; ALTIERI, Miguel A. Agroecology: the science of natural resource management 5 for poor farmers in marginal environments, Agriculture, Ecosystems and Environment 1971. Berkeley: Elsevier Science B.V., 2002. p. 1-24. 35 FOOD AND AGRICULTURE ORGANIZATION OF THE UNITED NATIONS. Agroecology for Food Security and Nutrition Proceedings of the FAO International Symposium. 18-19 September 2014, Rome, FAO. Legal developments in the progressive realization of the right to food, 2014, available at: < http://www.fao. org/3/a-i3892e.pdf $>$. Access on: 10 out. 2016.

36 ABREU, L. S. de; LAMINE C., BELLON S. Trajetórias da Agroecologia no Brasil: entre Movimentos Sociais, Redes Científicas e Políticas Públicas. In: CONGRESSO LATINO-AMERICANO DE AGROECOLOGIA, 2.; CONGRESSO BRASILEIRO DE AGROECOLOGIA, 6., 2009, Curitiba. Anais... Curitiba, 2009.

37 As shown in the following chapter in the case of Brazil. "application of the science of ecology to agricultural systems" ${ }^{38}$ with the aim of increasing agricultural production by optimizing the use of the local ecosystem and natural resources. Humans, together with the local and surrounding environment, are considered part of the ecosystem that generates positive socioeconomic and environmental effects. It incorporates local and indigenous farmer knowledge to create a socially and environmentally local-oriented agricultural practice.

Sustainability is addressed through more efficient use of local natural resources so as not to deplete the sources of land and water; and at the same time, create crops resilient to pests and adverse weather occasions caused by climate change. ${ }^{39}$ Studies suggest that locally developed crops are more adaptable and robust, especially because the transgenerational breeding was dictated by corresponding local ecological and social conditions. ${ }^{40}$ On a social level, public policy to increase research and farmers training in agroecology can empower small-scale farmers to produce for their owns subsistence and provide livelihoods to build a path out of poverty by selling the exceeding amount of food produced. Without heavily depending on external inputs, access to the market might be facilitated, especially into the growing market of organic products. ${ }^{41}$ Poor rural communities have an advantage on the implementation of agroecological practices because it is "relatively labor intensive, most effectively practiced on small plots of land and relies on locally produced inputs". ${ }^{42}$

An agroecological approach to public policy em-

38 SCHUTTER, Olivier de. Agroecology, a Tool for the Realization of the Right to Food. In: LICHTFOUSE, Eric (Ed.). Agroecology and Strategies for Climate Change. New York: Springer, 2012. p. 1-16.

39 See WESTRA, John; BOODY George. Challenges and benefits of developing multifunctional agroecosystems. In: BOHLEN, Patrick J.; HOUSE, Gar. (Ed.). Sustainable agroecosystem management. Integrating ecology, economics, and society. Boca Raton: CRC, 2009. p. 213-229.

40 MOKUWA, Alfred et al. Robustness and strategies of adaptation among farmer varieties of African rice (Oryza glaberrima) and Asian rice (Oryza sativa) across West Africa. PloS ONE, v. 8, n. 3, Mar. 2013.

41 For statistics on growing demand for organic products see LERNOUD, Julia; WILLER, Helga; SCHLATTER, Bernard. 'North America: current statistics'. In: (Ed.). The world of organic agriculture: statistics and emerging trends. Bonn: Research Institute of Organic Agriculture, 2014. p. 251.

42 ELVER, Hilal. Interim report of the Special Rapporteur on the right to food, Promotion and protection of human rights: human rights questions, including alternative approaches for improving the effective enjoyment of human rights and fundamental freedoms, UN Doc. A/70/287, 2015. p. 21. 
braces to tripartite State's obligations to progressively realize the HRF, as it respects existing access to food by preserving the environment and natural resources that allow for small-scale farmers and indigenous population to practice subsistence agriculture, often relying on their traditional knowledge. Additionally, it respects existing access to adequate food by promoting agricultural practices that produce food 'free from adverse substances'. The obligation to protect is implemented by protecting the environment from the negative effects of large-scale industrial agriculture, including climate change, that negatively affect the realization of the HRF. Water resources are protected from farming waste pollution as well as chemical fertilizers and pesticides. Lastly, public policy to incentive small-scale agroecological practices carries a great potential to fulfill the HRF as it creates the necessary condition for the most vulnerable to build a resilient and sustainable, market-oriented agricultural system.

States should invest in knowledge building through research and knowledge sharing through training and encourage self-organized, community networks and partnerships. ${ }^{43}$ Agroecology is a fairly new field of science that carries a great potential to be developed by biophysical and social science research. The Special Rapporteur for the HRF has called upon States to "encourage a major shift from current industrial agriculture to transformative activities such as conservation (agroecology) that supports the local food movement, protect smallholder farmers, empower women, respect food democracy, maintain environmental sustainability and facilitate a healthy diet." ${ }^{44}$

\section{Brazil as a STUdY CASE}

Whereas Brazil has a relatively high GDP, approximately 10 million people still live in extreme poverty in the country. ${ }^{45}$ Brazil is the world's fourth largest food

43 SCHUTTER, Olivier de. Agroecology, a Tool for the Realization of the Right to Food. In: LICHTFOUSE, Eric (Ed.). Agroecology and Strategies for Climate Change. New York: Springer, 2012. p. 1-16. p. 5.

44 ELVER, Hilal. Interim report of the Special Rapporteur on the right to food, Promotion and protection of human rights: human rights questions, including alternative approaches for improving the effective enjoyment of human rights and fundamental freedoms, UN Doc. A/70/287, 2015. p. 24.

45 WORLD BANK. Poverty and Equity Data, Country Dashboard: exporter in the world ${ }^{46}$ and one may infer that for such reason it has sufficient capacity to meet its internal demands on food. However, in 2013, 23\% of Brazilian households faced food insecurity, ${ }^{47}$ especially among the rural population of the Northeast region of the country. ${ }^{48}$ The Brazilian situation might be taken as an example of the current global scenario, in which the primary hindrance to the fulfillment of the HRF is not directly related to food production capacity, but rather to food access and utilization.

Moreover, small-hold holders and family farming play a key role for the implementation of the HRF in Brazil to the extent that such groups represent relevant food production sources, and, paradoxically, also are the most vulnerable ones in regard to food insecurity, and climate change effects, such as drought and floods. Thus, agroecology can be a relevant tool to advance the HRF in Brazil, by enhancing direct access to food and by providing a way out of poverty by the commerce of the exceeding amount of food produced.

Furthermore we will briefly overview the implementation of the HRF in Brazil in general and then focus on the effectiveness of the national public policy to foster agroecological practices as a means of progressive realizing Brazil's international obligation for the HRF.

\section{BRIEF OVERVIEW ON THE IMPLEMENTATION OF THE HRF IN BRAZIL}

Brazil has become an international benchmark in the fight against hunger due to the incorporation of the topic in its agenda as a top priority since 2002, implementing national policies and recognizing the intrinsic link between poverty and hunger with the ultimate goal to break the vicious circle of hunger.

Brazil. 2015. Available at: <http://povertydata.worldbank.org/poverty/country/BRA>. Access on: 30 out. 2016.

46 FOOD AND AGRICULTURE ORGANIZATION OF THE UNITED NATIONS. FAOSTAT. 2015. Available at: < http://faostat.fao.org/beta/en/\#compare> Access on: 30 out. 2016. 47 INSTITUTO BRASILEIRO DE GEOGRAFIA E ESTATISTICA. Segurança Alimentar. 2013. Disponível em: <http://www.ibge. gov.br/home/estatistica/populacao/seguranca_alimentar_2013/>. Acesso em: 30 out. 2016.

48 INSTITUO BRASILEIRO DE GEOGRAFIA E ESTATÍSTICA. Pesquisa Nacional por Amostra de Domicílios: 2004-2009. Available at: <http://biblioteca.ibge.gov.br/visualizacao/livros/liv47241. pdf>. Access on: 30 out. 2016. 
In 2003 the Brazilian government implemented the internationally acknowledged Zero Hunger Program through which hunger, extreme poverty and inequality were addressed holistically with measures to increase access to food, generate jobs and increased income, intensify the agrarian reform and incentive family farming and education.

As part of the Zero Hunger Program, the government implemented also in 2003, the Family Allowance Program (Programa Bolsa Familia), through which enrolled families receive cash transfers conditional upon keeping their children in school and attending preventive health care visits. According to the World Bank, ten years after Bolsa Familia, Brazil has more than halved its extreme poverty - from 9.7 to $4.3 \%$ of the population ${ }^{49}$. Alongside with this impressive reduction in social inequality, Bolsa Familia also provided useful data for scaling other social programs, such as the Brazil Without Misery Plan, that targeted extreme poverty eradication through more comprehensive and systematic poverty reduction actions such as productive inclusion, income security and access to public services.

As a result of such actions, 29 million people were lifted out of poverty between 2003 and 2014. Socio-economic inequality dropped $6.6 \%$ points in the Gini coefficient in the same period (from 58.1 to 51.5). The income level of the poorest $40 \%$ of the population rose, on average, $7.1 \%$ in real terms, compared to a $4.4 \%$ income growth for the population as a whole..$^{50}$ Specifically regarding the fight against hunger and undernourishment, the proportion of people suffering undernourishment decreased from $7.5 \%$ in $2008-2010$ to $6.9 \%$ in $2011-2013 .{ }^{51}$

Finally, in 2010, Brazil integrated the HRF in its Federal Constitution, granting irrevocable validity to such right as a non-amendable clause. ${ }^{52}$ This was a milestone for the development of a legal framework that applies a

49 WORLD BANK. Bolsa Familia: Brazil's Quiet Revolution. 2013. Available at: <http://www.worldbank.org/en/news/opinion/2013/11/04/bolsa-familia-Brazil-quiet-revolution> Access on: 30 out. 2016.

50 WORLD BANK. Countries, Brazil, overview. 2015. Available at: $<$ http://www.worldbank.org/en/country/brazil/overview>. Access on: 30 out. 2016.

51 FOOD AND AGRICULTURE ORGANIZATION OF THE UNITED NATIONS. Food and Agriculture Policy Decision Analyses. Available at: <http://www.fao.org/docrep/field/009/i3759e/ i3759e.pdf $>$ Access on: 30 out. 2016.

52 Constitutional Amendment No. 64, enacted on 02/04/2010. right-based approach to food security in Brazil. National law reacted to the constitutional amendment and, in the same year, the National Food and Nutritional Security System (SISAN) was created through presidential decree No. 7.272 with the goal of fully implementing the HRF and set the guidelines for the National Plan for Food and Nutrition Security (PNSAN). PNSAN aimed to achieving food security through inter-sectoral public actions and policies, guided by the legal framework of the HRF.

\section{INSTITUTIONAL FRAMEWORK OF THE BRAZILIAN STATE FOR THE IMPLEMENTATION OF HUMAN RIGHT TO FOOD}

The agricultural sector is seen in Brazil as a key economic area while at the same time as a decisive instrument for social development. For such reason, Ziegler diagnoses about the schizophrenic State behavior regarding the realization of the HRF can also be identified in Brazil. Institutionally, the agriculture sector is oriented both by the Ministry of Agriculture, Livestock and Food Supply (MAPA), mainly focused on the economic aspects of agriculture, such as agribusiness, enhancing food production and economic growth through land management risk, credit and trade; as well as by the Ministry of Social and Agrarian Development (MDS), responsible for social programs and food security. $\mathrm{Pu}-$ blic policies towards food security are under the budget and coordination of the MDS, whereas MAPA collaborates with the work of MDS within food security and nutrition programs, specially with measures to improve supply chains from family agriculture, as will be further detailed. On one hand, this separated structure grants a positive level of autonomy for the implementation of social development programs mainstreaming food security. On the other hand, it fails to incorporate food security and the HRF with the national agricultural strategy, including the alignment with the commercial use of agriculture and international trade. This current structure misses the opportunity to apply a holistic approach to food security, in which economic as well as social and environmental aspects are integrated in national agricultural strategy, and accentuates the schizophrenic tendency, as will be evidenced in more detail below.

It is important to point out that the Brazilian agra- 
rian and food security institutional framework underwent significant changes in 2016 due to recent restructuring within the Federal Government, performed by the Interim President, as a result of political instability. ${ }^{53}$ The Ministry of Agrarian Development (MDA), originally responsible for land reform affairs, was merged with the Ministry of Social Development and Fight against Hunger and is currently referred to as Ministry of Social and Agrarian Development (MDS). Moreover, the Special Secretariat for Family Agriculture as well as the National Institute of Colonization and Agrarian Reform (INCRA) are no longer related or subject to the former MDA, but lie under the Chief Staff of the Federal Government ${ }^{54}$.

Such institutional changes, including budget and staff, must be carefully observed so as not to lead to a negative impact on the continuity of ongoing social programs originally implemented by the merged institutions and that have a decisive participation in the progressive realization of the HRF. Otherwise, this recent restructuring might contribute to existing chronic disarticulation within Brazilian institutions and characterize a breach of the international obligation of non-regression towards the HRF.

Civil society has also played a decisive role in the advancement of the HRF in Brazil ${ }^{55}$ and as a response to their demands, the Brazilian State has, in a pioneering fashion, created the National Food Security Council (CONSEA), a political and social advisory body for the articulation between government and civil society and for the proposing guidelines for actions related to food security. CONSEA was originally created in 1993, interrupted its functions in 1995 and regained its political force in 2003 for the implementation of the Hunger Zero Program.

In the current context, MAPA and MDS are the most relevant structures for policy making both on agriculture and food security, whereas CONSEA and the Special Secretariat for Family Agriculture contribute for the much needed integration between MAPA and MDS, reconciling agriculture as an instrument for economic growth and social development.

53 Federal Law No. 13.341, enacted on 29.09.2016.

54 Decree No. 8.865 enacted on 29.09.2016.

55 For a detailed analyses of the role of civil society in the advancement of public policies towards the realization of the HRF see: KRACHT, U. (Ed.). Food and Human Rights in Development. Oxford: Intersentia, 2007. p.181-212.

\section{BRIEF OVERVIEW ON PUBLIC POLICY TOWARDS} THE REALIZATION OF THE HRF

The main public policies adopted by the Brazilian State that set guidelines for agricultural practices and are intertwined with or might have influence on agroecology practices, are the Multiannual Plan (PPA), which is the action plan of MAPA, and the Family Farming Harvest Plan (FFHP), which defines the strategic measures on family agriculture and food security, formerly elaborated and coordinated by MDA and currently under the authority of the Chief Staff of the Federal Government and being implemented by the Special Secretariat for Family Agriculture.

The PPA has a decisive relevance for the national agricultural sector and food supply as it sets the priority measures to be adopted by the national agriculture head institution, MAPA. Even though, MAPA is also technically responsible for national food security, in practice the measures implemented are mainly aimed at increasing production and improving trade, as evidenced by the analyses of its competencies established by law opposed to the actions detailed in the PPA. Regarding the measures implemented by MAPA towards food security, the 2012-2015 PPA, contains only one food and nutritional security program, that is under the MDS coordination, and one family agriculture program, that is under the coordination of the Special Secretariat for Family Agriculture. Both programs count with the contribution of MAPA exclusively for the purposes of improving the related food supply chain and credit lines. The fact that MAPA, the institution responsible for agriculture in Brazil, has only limited inputs in food security policies contributes for the lack of integration of HRF obligations into national strategy for agriculture and agribusiness.

The FFHP, developed by the former MDA on an annual basis since 2002 details strategic forms of support to the sector. The current plan (2016-2017) establishes (1) specific credit lines with lower interest rates and also related to agroecological production under the $\mathrm{Na}$ tional Program for the Strengthening of Family Agriculture (PRONAF), (2) insurances for crops impaired due to climate change and climate disaster, (3) technical assistance to farmers, (4) incentives for cooperative activities, (5) support for trade under mandatory public acquisition of food from family farmers, especially under 
the Food Acquisition Program (PAA), which enables the acquisition of food production from small holder farmers by public authorities such as schools and hospitals, (6) measures to empower women and young people on agriculture, and (7) land reform.

These measures have the potential to satisfy many of the requirements made by international law for the realization of the HRF and encompasses commitments made the Brazilian State in the SDG as well as in the VGRF and the call made by the Special Rapporteur towards small-scale agriculture incentives and inclusion of woman in social planning, exposed above. Nevertheless, it is important to observe that the FFHP was originally developed and implemented by MDA, which has been merged into MDS, according to the recent institutional reform. Therewith, the FFHP is now under the coordination of a different institution (Chief Staff of the Federal Government) and must be closely observed in order to make sure the institutional reform does not harm the effective continuation of the program. Eventual impairments on the effective continuation of the FFHP, causing a lower access by rural families to food security, might constitute a breach of State's obligation for the progressive realization of the HRF.

Other relevant public policies implemented after the incorporation of the HRF in the Federal Constitution in 2010 are the PNSAN, mentioned above, and the National Policy for Technical Assistance and Rural Extension for Family Agriculture and Agrarian Reform (PNATER) which was implemented alongside with the National Program of Technical Assistance and Rural Extension in Family Agriculture and Agrarian Reform (PRONATER), also known as the Technical Assistance and Rural Extension Program (ATER). ${ }^{56}$ PRONATER and ATER are focused on providing education through free technical service and rural extension for small holder farmers, family farmers settled by the agrarian reform, riverine (ribeirinhos), indigenous people, quilombolas, fisherfolk among other vulnerable groups. The ATER program contributed to empower small holder farmers through direct knowledge exchange and providing access to information. Its structure is now also being used to promote, disseminate and further develop agroecological practices and knowledge.

The object of the public policies mentioned above represent a promising path towards the progressive

56 Federal Law No. 12.188, enacted on 11.01.2010. implementation of the HRF as they incorporate different aspect of the normative content of the HRF. Significant measures can be identified in regard to the State's obligation to fulfill the HRF promoting small-scale farmers incentives. Nevertheless, it is important to point out a certain lack of integration of such public policies among the different governmental institutions which might lead to the overruling of economic interest over efforts to realize the HRF, especially within MAPA structure. Despite efforts to integrate such policies within different Ministries, as above evidenced, such public policies intend mainly to address different concerns from the Brazilian State in regard to its agricultural development, either related to trade/economic growth, positioning Brazil as a competitor in the international food market, or the Brazilian international obligation to realize the HRF by guaranteeing access to food for its population and fighting undernutrition and poverty.

\section{Agroecology public policy for the REALIZATION OF THE HRF IN BRAZIL}

Even though the main Brazilian public policies related to food, agriculture and poverty eradication carried out over the last decade, have indeed decreased social inequality and provided access to food, as previously mentioned, the Brazilian State still faces the challenge of providing food security for $23 \%$ of its population, especially in rural areas of environmentally damaged regions such as the Brazilian Northeast. As seen above, agroecological practices represent an important path to address social and sustainability challenges at the same time.

In this context, the Federal Government enacted in 2012 the National Policy for Agroecology and Organic Production (PNAPO) through Decree No. 7.794 envisaging the integration, coordination and adaptation of public policies and programs to foster actions for a transition to agroecological and organic production, contributing to sustainable development and the population's quality of life through sustainable use of natural resources, supply and consumption of healthy foods ${ }^{57}$.

From an institutional standpoint, PNAPO is under the Special Secretariat for Family Agriculture, currently

57 PNAPO, art. 1. 
under the Chief Staff of the Federal Government. The Secretariat is competent to address subjects related to family farming, small holder farmers and other vulnerable groups.

The main instrument for the implementation of the PNAPO is the National Plan for Agroecology and Organic Production (PLANAPO). Up to now, the government has developed two national plans, the first one refers to the period of 2013 to 2015 (PLANAPO 20132015) and the second one refers to period of 2016 to 2019 (PLANAPO 2016-2019). According to the report on the monitoring of results of the PLANAPO 20132015, this first plan enabled an approximation between public and private actors interested in agroecology and contributed to the incorporation of the subject in further public policies, as a new field of science.

The PLANAPO 2016-2019 incorporates the experience acquired during the inaugural first period and addresses important obstacles in the implementation of the HRF, including the lack of institutional integration and contradictions in public policy for food security, exposed above. It also recognizes the need for a holistic approach so that measures implemented by different public authorities do not have negative effects on gains achieved through the implementation of agroecological practices. Nevertheless, as seen above, public policy alone has limited effectiveness within the not fully integrated institutional framework exposed.

In order to achieve such needed integration, the plan is subject to two different instances, the first one is the Inter-ministerial Chamber, responsible for the drafting, execution and monitoring of the plan, formed by representatives of the MDS; MAPA; General Secretariat of the Presidency; Ministry of Finance; Ministry of Environment; Ministry of Education; Ministry of Health; Ministry of Science, Technology and Innovation; and Ministry of Fisheries and Aquaculture. The second one is the National Commission, composed by an equal number of members from civil society and Government/public authorities, who will collaborate on the drafting of the plan and engage civil society in its execution and monitoring.

As a result of the engagement of these several actors who are experts on different subjects, the PLANAPO 2016-2019 has highly cross-cutting public policy structure encompassing six major topics: (1) production; (2) use and conservation of natural resources; (3) knowled- ge; (4) trade and consumption; (5) land and territory; (6) socio-biodiversity.

The first topic encompasses multiple aspects of production, including financial support such as insurance and credit lines. Based on the existing PRONAF structures, a specific line of credit for agroecological and organic production (PRONAF Produtivo Orientado) was created together with a specific line of credit conditioned to low GHG emissions on agriculture. The crosscutting nature of PLANAPO is evidenced by the tackling of the climate change even under a sector with high economic background like production.

Another relevant aspect addressed under the topic of production is the conclusion of the National Program for Use Reduction of Agrochemicals (PRONARA). The PRONARA was concluded after long civil society mobilization and articulation with the governmental authorities based on the target established by the first PLANAPO 2013-2015. However, it has not yet been implemented. The advancement of the revaluation on the granting of authorizations for uses of agrochemicals in Brazil is also foreseen to take place during the period of the PLANAPO 2016-2019.

Furthermore, both plans set forth measures to ensure the quality of the organic production, particularly through certification and monitoring for quality control; to provide scale and foster agroecology; actions aiming for recognizing increasing the access to educational projects/programs such as ATER by women and granting credit lines and access to trade policies such as PAA. Such public policy have a significant impact on the realization of the HRF because of their potential to increase sustainable agriculture production and empowering minorities through education and access to credit. Moreover, the certification and quality control structures follow the international trend towards organic food certification and might be a building block in the integration of small-hold organic farmers into the growing international market.

On the subject of sustainable use of resources, PLANAPO 2013-2015 mapped the extractive production and socio-biodiversity products by traditional populations and performed the strengthening of educational program such as ATER specifically related to extractive activities. Moreover, the PLANAPO 2013-2015 resulted in an elaboration of technical parameters for the sustainable management of species and non-timber 
forest products, the consolidation of documents containing technical guidelines for adoption good management practices for organic sustainable harvesting and preparation of contract guidance for extractive producers, which will be disclosed and used during the implementation of PLANAPO 2016-2019. In order to use Brazilian natural resources in an effective manner towards the fulfillment of the HRF, the PLANAPO also aims for a nutritional mapping of native species of flora with relevant nutritional value to support initiatives related to food security and nutrition in order to diversify the Brazilian population diet. This action is another good example of the implementation by the Brazilian State of the HRF to the extent it is not focused only on food access, but also on food adequacy. For such purposes, once again, other relevant issues are encompassed within the strategy to effectively fulfill the HRF, such as sustainable agriculture practices though the establishment of good management for organic sustainable harvesting and extractive activities and empowering of traditional populations through education.

Additionally, the PLANAPO 2016-2019 included measures to disseminate technologies and practices for the recovery of degraded areas by developing a system of information accessible to farmers. The plan also details actions toward hydric security with a focus on the semi-arid regions of the country. This holistic approach is essential to address the challenges faced by the rural population of land degraded or dry areas so that they can rebuilt a sustainable ecosystem that allows them to extract their livelihoods from agriculture.

Within the subject of capacity building, the plan establishes actions for scientific research and the use of regional traditional knowledge as a means to increase and improve agroecological production, articulating with other public policies such as ATER.

The PLANAPO also addresses trade and market entry for agroecological products to allow the small-scale farmers not only to provide for their own dietary needs but also to construct a way out of poverty, and as a consequence, out of food insecurity upon the application of agroecological practices.

On the topic of land and territory, the amplification and consolidation of agroecology practices relies upon the access of farmers to land through land reform as well as the granting of public support for effective productive settlement of landless people. The PLANA-
PO 2016-2019 incorporates such assumption and establishes a set of measures to be undertaken aiming the creation of more sustainable land reform settlements.

In quilombola areas, two major challenges shall be addressed by PLANAPO in the following years: (1) review rules governing the procedure for identification and demarcation and (2) the preparation of the First National Strategic Plan for Entitlement targeting the completion of pending administrative procedures for granting of quilombola territories entitlements by INCRA.

Another important aspect tackled by the PLANAPO 2016-2019 is social biodiversity that addresses the relationship between traditional communities such as indigenous people, quilombolas, rubber tappers (seringueiros), riverine, fisherfolk, babassu coconut breakers and their environment. The common feature of traditional communities is the extraction of their livelihoods from the natural environment and are highly dependent on the forest and the natural forest systems and services. Traditional and extractive knowledge systems are built over centuries of coexistence of the traditional communities with their environment. Thus, it is essential to protect biodiversity so that traditional communities can continue to extract their livelihoods from the natural environment as well as to secure sustainable access to their traditional land or land to which their identity is bound. In this sense, the PLANAPO has the potential to effectively implement the State obligation to protect the HRF of all people, including vulnerable communities.

This short analysis of Brazil's implementation of an agroecological approach to achieve food security does not intend to exhaust the subject but instead highlight important aspects of it to allow for verifying its correspondence with the normative content of the HRF and State's international legal obligation for its realization.

From the framework analyzed above, it is possible to identify a holistic rights-based approach to food security in which different layers of State responsibility are involved. The PLANAPO has a great potential for the full realization of the normative content of HRF by the Brazilian State because its addresses food availability, by increasing production and at the same time allowing for a greater variety. Food Accessibility is increased in so far as the incentives and assistance for food production is given to the most vulnerable population and reduces its food insecurity 
once they can consume their own production. Food adequacy in increased in the application of agroecology by Brazilian public policy by means of producing food free from adverse substances. Finally, the sustainability aspect of the normative content of the HRF is complied with by creating a healthy ecosystem through agroecological practices, capable of producing food for current and future generations, without degradation the soil and natural resources. Moreover, it complies with specific international requirements and soft law commitments as it supports the local food movement and small holder farmers, empowers women and vulnerable groups, respects traditional knowledge while fostering economic growth and tackling social inequality, seeks environmental sustainability and facilitates a healthy and nutritionally balanced diet.

Furthermore, the agroecological public policy embraces the tripartite State's obligations to progressively realize the HRF as it respect existing access to food by preserving the environment and environmental services that allow for different groups to extract their livelihoods. An important step taken under the State's obligation to protect the HRF is the reevaluation of the use of agrochemicals through PRONARA. If this plan is effectively implemented, together with other measures to improve access to organic food, the right of every person to have access to food free of adverse substances will be protected from activities from third parties. Accordingly, the ecosystems that allow for the realization of the HRF will also be protected from the excessive use of agrochemicals by third parties. Finally, the obligation to fulfill the HRF is progressively addressed by incorporating the latest scientific evidence on agroecology as means to achieve sustainable agricultural production and by creating the necessary condition for the most vulnerable people to build a resilient and sustainable, market-oriented agricultural system that might provide for their own subsistence and way out of poverty. The exposed aspects of the agroecological public policy framework also allow for identifying the presence of all elements of the normative content of the HRF.

Another positive aspect to be extracted from the analyses above is that the implementation of agroecology practices avail existing programs, such as PRONAF, PAA and ATER, utilizing the already successful structures and mechanism that have served as valuable tools in the fight against hunger in Brazil, enabling and facilitating the incorporation of agroecology within the institutional framework.

\section{Final Conclusions}

The international legal framework of the HRF has developed a clear outline in the last decades establishing well-defined state obligations and increasingly developing mechanism for its eligibility. The concept of food security as means for the implementation of the HRF is subject to constant review. Concerns over the effects of climate change in general and especially on the most vulnerable rural populations have raised the support in multiple sectors of society for the expansion and application of agroecological practices that incorporate social, economic and sustainability aspects of food production.

Brazil has taken significant steps in the progressive implementation of the HRF since 2002 and has reached a decisive milestone in building a human rights-based approach to food security by incorporating the HRF in its Federal Constitution in 2010. Even though there have been significant advancements since then, including the development and incentives for agroecological practices, agricultural public policy still reflects the schizophrenic behavior of States identified by Ziegler. On one hand the Brazilian State recognizes the HRF and takes measures towards its implementation. On the other hand, the State takes measures that negatively affect the realization of the HRF. This dichotomy can be clearly identified in the analyses of the institutional framework, in which there are two different institutions, one responsible for agricultural development (MAPA) an one responsible for food security and social development (MDS). A brief analyses of public policy applied by both institutions show a lack of integration and coordination so that MAPA, the head agricultural institutions does not prioritize the fight against hunger, but only gives limited support to MDS specifically focused on credit lines and food supply chain. MAPA misses the opportunity to incorporate the HRF in its general national agrarian strategy.

Important enough to merit attention are the institutional adjustments recently applied to the complex net of institutions involved in public policy to achieve food security and the HRF. Political instability led to reforms in the institutional framework that if not well monitored might lead to retrogression in the realization of the HRF, which is expressly forbidden by international law and would imply a breach by the Brazilian State of its international legal obligation. 
The agroecological framework applied by the Brazilian State as of 2013 addresses the four elements of the normative content of the HRF, improving its availability, accessibility, adequacy and sustainability, while at the same time applying the first steps towards the recommendation made the Special Rapporteur in the Report to the General Assembly nr. A/70/287 from 5.08.2015 to shift into conservation agriculture. This features Brazil as a leader in agroecological public policy development and represents an outstanding advance towards the progressive realization of the HRF. It addresses many issues previously neglected by the State such as the integration of public institutions and policies. The integrating and crosscutting aspects of the agroecological framework represent an opportunity to smooth the schizophrenic behavior of the State and take steps towards solving the paradox of a leading food export country that is not able to adequately feed $23 \%$ of its population. The push for large-scale export agricultural export might have economical reasoning but does not constitute State obligations toward the progressive realization of the HRF inasmuch as it does not respond for current or future demands for access to food.

Other important contributions of the agroecological framework are the strengthening of measures to protect cultural minorities and therewith implement the State's obligation not to discriminate, established in Art. 2, para. 2 and Art. 3 ICESCR. Additionally, the agroecological framework contributes to build environmental sustainability and resilience for those cultural minorities, while ate the same time benefiting the collectivity by allowing for food production with a significant lower index of agrochemical uses. The framework builds an important legal base that needs to be continuously reviewed to integrate the knowledge and participation of multiple stakeholders.

Nevertheless, agroecology is not a panacea to the social, political and environmental challenges faced to finally end hunger and malnutrition worldwide. The deep roots of social injustice and consequent hunger and poverty cannot be underestimated. The fight against hunger must count on diligent and inexhaustible efforts in terms of political will, public policy, technical and legal research, investment, capacity building and civil society mobilization.

\section{References}

ABREU, L. S. de; LAMINE C., BELLON S. Trajetórias da Agroecologia no Brasil: entre Movimentos Sociais, Redes Científicas e Políticas Públicas. In: CONGRESSO LATINO-AMERICANO DE AGROECOLOGIA, 2.; CONGRESSO BRASILEIRO DE AGROECOLOGIA, 6., 2009, Curitiba. Anais... Curitiba, 2009.

ALSTON, Phillip. Ships Passing in the Night: The Current State of the Human Rights and Development Debate Seen Through the Lens of the Millennium Development Goals. Human Rights Quarterly, v. 27, p. 755-829, Aug. 2005.

BAKKER, Christine. Climate change and right to life, Limits and potentialities of the human rights protection system. In: QUIRICO, Ottavio; BOUMGHAR, Mouloud. Climate change and human rights: an international and comparative law perspective. New York: Routledge, 2016. p. 71-89.

BROWN, Lynn; GENTILINI, Ugo. On the edge: the role of food-based safety nets in helping vulnerable households manage food insecurity. In: GUHA-KHASNOBIS, Basudeb; ARCHARYA, Shabd S.; DAVIS, Benjamin (Ed.). Food insecurity, vulnerability and buman rights failure, (no location). Basingstoke: Palgrave Mcmillan, 2007. p. 82-105.

COHEN, M. J. C.; ABERMAN, N. L.; THOMPSON, B. Impact of Climate Change and Bioenergy on Nutrition. Rome: FAO, 2003.

COURTIS, Christian. The right to food as a justiciable right: challenges and strategies. Max Planck Yearbook of United Nations Law, v. 11, p. 317-337, 2007.

EIDE, Asbjørn. Final Report of the Special Rapporteur on the right to adequate food of the UN Sub-Comission on Prevention of Discrimination and Protection of Minorities, 1987, UN Doc. E/CN.4/Sub.2/1987/23. This study was later updated in 1999, Updated Study on the Right to Food, UN Doc. E/CN.4/Sub.2/1999/12, 28 June 1999.

ELVER, Hilal. Interim report of the Special Rapporteur on the right to food, Promotion and protection of human rights: human rights questions, including alternative approaches for improving the effective enjoyment of human rights and fundamental freedoms, UN Doc. A/70/287, 2015, p. 20. 
EVENSON, R. E.; GOLLIN, D. Assessing the impact of the green revolution: 1960 to 2000. Science, v. 300, n. 5620, p. 758-762, May. 2003.

FARMER, B. H. Perspectives on the 'Green Revolution' in South Asia. Modern Asian Studies, v. 20, n. 01, p. 175-199, 1986.

FOOD AND AGRICULTURE ORGANIZATION OF THE UNITED NATIONS. Agroecology for Food Security and Nutrition Proceedings of the FAO International Symposium. 18-19 September 2014, Rome, FAO. Legal developments in the progressive realization of the right to food, 2014, available at: <http://www. fao.org/3/a-i3892e.pdf>. Access on: 10 out. 2016.

FOOD AND AGRICULTURE ORGANIZATION OF THE UNITED NATIONS. Anti-Hunger Programme. A twin-track approach to hunger reduction: priorities for national and international actions. Rome: FAO, 2002, p. iii - first page of the executive summary. Available at: <ftp://ftp.fao.org/docrep/fao/006/j0563e/ j0563e00.pdf $>$. Access on: 06 jan. 2017.

FOOD AND AGRICULTURE ORGANIZATION OF THE UNITED NATIONS. FAOSTAT. 2015. Available at: <http://faostat.fao.org/beta/en/\#compare> Access on: 30 out. 2016.

FOOD AND AGRICULTURE ORGANIZATION OF THE UNITED NATIONS. Food and Agriculture Policy Decision Analyses. Available at: <http://www.fao. org/docrep/field/009/i3759e/i3759e.pdf > Access on: 30 out. 2016.

FOOD AND AGRICULTURE ORGANIZATION OF THE UNITED NATIONS. Implementing the Right to Adequate Food: The Outcome of Six Case Studies, IGWG RTFG Information Paper No. 4. Rome: FAO, 2004.

FOOD AND AGRICULTURE ORGANIZATION OF THE UNITED NATIONS. Small-scale Agriculture for Inclusive Development in the Near East and North Africa. 2015. Available at: <http://www.fao.org/3/a-au207e. pdf $>$. Access on: 28 out. 2016.

FOOD AND AGRICULTURE ORGANIZATION OF THE UNITED NATIONS. The State of Food Insecurity in the World. 2002. Foreword. Available at: <http://www.fao.org/docrep/005/y7352e/y7352e02. htm\#TopOfPage $>$. Access on: 15 out. 2016.

FOOD AND AGRICULTURE ORGANIZATION
OF THE UNITED NATIONS. The State of Food Insecurity in the World 2105. Rome: FAO, 2015. p. 26. Available at: <http://www.fao.org/3/a-i4646e/index.html> Access on: 15 out. 2016.

FOOD AND AGRICULTURE ORGANIZATION OF THE UNITED NATIONS. Trade Reforms and Food Security. Rome: FAO, 2003. p. 25-33. Available at: <ftp:/ / ftp.fao.org/docrep/fao/005/y4671e/y4671e00.pdf $>$. Access on: 21 out. 2016.

FOOD AND AGRICULTURE ORGANIZATION OF THE UNITED NATIONS; BIOVERSITY INTERNATIONAL. Sustainable Agriculture and Rural Development (SARD) Policy Brief 11, 2007.

FOOD AND AGRICULTURE ORGANIZATION OF THE UNITED NATIONS; IFAD; WFP. The State of Food Insecurity in the World 2015. Meeting the 2015 international hunger targets: taking stock of uneven progress. Rome: FAO, 2015. Available at: <http://www. fao.org/3/a-i4646e.pdf>. Access on: 06 jan. 2017.

FOOD AND AGRICULTURE ORGANIZATION OF THE UNITED NATIONS; IFAD; WFP. Reducing Poverty and Hunger: The critical Role of Financing Food, Agriculture and Rural Development. Rome: FAO, 2002. p. 12. Available at: <ftp:/ /ftp.fao.org/docrep/fao/003/ Y6265E/Y6265E.pdf>. Access on: 06 jan. 2017.

HERRING, Ronald J. How is food political? market, state and knowledge. In: (Ed.). The Oxford bandbook of food, politics and society. New York: Oxford University, 2015. p. 3-40.

INSTITUO BRASILEIRO DE GEOGRAFIA E ESTATÍSTICA. Pesquisa Nacional por Amostra de Domicilios: 2004-2009. Available at: <http://biblioteca. ibge.gov.br/visualizacao/livros/liv47241.pdf $>$. Access on: 30 out. 2016 .

INSTITUO BRASILEIRO DE GEOGRAFIA E ESTATÍSTICA. Segurança alimentar. 2013. Available at: <http://www.ibge.gov.br/home/estatistica/populacao/seguranca_alimentar_2013/>. Access on: 30 DEZ. 2016.

LERNOUD, Julia; WILLER, Helga; SCHLAT'TER, Bernard. 'North America: current statistics'. In: (Ed.). The world of organic agriculture: statistics and emerging trends. Bonn: Research Institute of Organic Agriculture, 2014.

LOCKIE, Stewart; CARPENTER, David. (Ed.). Agri- 
culture, biodiversity and markets. Livelihoods and agroecology in comparative perspective. London: Earthscan, 2010 .

MILLENNIUM ECOSYSTEM ASSESSMENT. Ecosystems and Human Well-being: A Framework for Assessment. Washington, DC: World Resources Institute, 2005. p. 64. Available at: <http://www.millenniumassessment.org/documents/document.300.aspx.pdf> Access on: 20 out. 2016.

MOKUWA, Alfred et al. Robustness and strategies of adaptation among farmer varieties of African rice (Oryza glaberrima) and Asian rice (Oryza sativa) across West Africa. PloS ONE, v. 8, n. 3, Mar. 2013.

PAARLBERG, Robert L. Food Politics: what everyone needs to know. New York: Oxfrod University, 2013.

PERFECTO, Ivette; VANDERMEER, John; WRIGHT, Angus. Nature's Matrix: Linking agriculture, conservation and food sovereignty. London: Earthscan, 2009.

RAE, Isabella; THOMAS, Julian; VIDAR, Margret. The Right to Food as a Fundamental Human Right: FAO's Experience. In: GUHA-KHASNOBIS, Basudeb; ACHARYA, Shabd S.; DAVIS, Benjamin (Ed.). Food insecurity, vulnerability and human rights failure. New York: United Nations University, 2007.

SCHUT'TER, Olivier de. Agroecology, a Tool for the Realization of the Right to Food. In: LICHTFOUSE, Eric (Ed.). Agroecology and Strategies for Climate Change. New York: Springer, 2012. p. 1-16.

SCHUT'TER, Olivier de; VANLOQUEREN, G. The New green revolution: how twenty-first-century science can feed the world. The Solution Journal. 2011. Available at: <https://dlc.dlib.indiana.edu/dlc/ bitstream/handle/10535/7482/The\%20New\%20 Green\%20Revolution_\%20How\%20Twenty-FirstCentury $\% 20$ Science $\% 20$ Can $\% 20$ Feed $\% 20$ the $\% 20$ World.pdf?sequence $=1 \&$ is Allowed $=\mathrm{y}>$. Access on: 28 out.2016.

TOMUSCHAT, Christian. Human rights: between idealism and realism. 3. ed. New York: Oxford University, 2014.
VALENTE, Flavio L. S. The human right to food movement in Brazil. In: EIDE, W. B.; KRACHT, U. (Ed.). Food and human rights in development. Oxford: Intersentia, 2007. p.181-212.

WARNER, Keith Douglass. Agroecology in action: extending alternative agriculture through social networks. Massachusetts: Massachusetts Institute of Technology, 2007.

WEINGÄRTNER, Lioba; TRENTMANN, Claudia (Ed.). Handbuch welternährung. Frankfurt: Campus Verlag, 2010.

WESTRA, John; BOODY George. Challenges and benefits of developing multifunctional agroecosystems. In: BOHLEN, Patrick J.; HOUSE, Gar. (Ed.). Sustainable agroecosystem management. Integrating ecology, economics, and society. Boca Raton: CRC, 2009. p. 213-229.

WILLER, Helga; YUSSEFI-MENZLER, Minou; SORENSEN, Neil (Ed.). The world of organic agriculture: statistics and emerging trends. Bonn: IFOAM, 2008.

WORLD BANK. Bolsa Familia: Brazil's quiet revolution. 2013. Available at: <http://www.worldbank.org/en/ news/opinion/2013/11/04/bolsa-familia-Brazil-quietrevolution>. Access on: 30 out. 2016.

WORLD BANK. Poverty and equity data, country dasbboard: Brazil. 2015. Available at: <http://povertydata. worldbank.org/poverty/country/BRA>. Access on: 30 out. 2016.

WORLD BANK. Rural Development Unit South Asia Region. india revitalizing punjab's agriculture, report no. 37069, september. 2013. Available at: <https:// openknowledge.worldbank.org/bitstream/handle/109 86/14433/370690IN0Revit1white0cover01PUBLIC1. pdf? sequence $=1$ \&is Allowed $=y>$. Access in: 20 out. 2016.

ZIEGLER, Jean et al. The Fight for the right to food: lessons learned. Geneva: The Graduate Institute Publications, 2011. 
Para publicar na Revista de Direito Internacional, acesse o endereço eletrônico www.rdi.uniceub.br ou www.brazilianjournal.org.

Observe as normas de publicação, para facilitar e agilizar o trabalho de edição. 